\title{
A Comparative Study of Urban Expansion in Beijing, Tianjin and Tangshan from the 1970s to 2013
}

\author{
Zengxiang Zhang ${ }^{1}$, $\mathrm{Na} \mathrm{Li}^{1,2, *}$, Xiao Wang ${ }^{1}$, Fang Liu ${ }^{1}$ and Linping Yang ${ }^{1}$ \\ 1 Institute of Remote Sensing and Digital Earth, Chinese Academy of Sciences, Beijing 100101, China; \\ zx_zhang@263.net (Z.Z.); Wangxiao98@radi.ac.cn (X.W.); liufang@radi.ac.cn (F.L.); \\ gis_yanglinping@126.com (L.Y.) \\ 2 University of Chinese Academy of Sciences, Beijing 100049, China \\ * Correspondence: lina@radi.ac.cn; Tel.: +86-10-6488-9205; Fax: +86-10-6488-9203
}

Academic Editors: Lars Eklundh, Petri Pellikka, Ruiliang Pu, Parth Sarathi Roy and Prasad S. Thenkabail Received: 12 March 2016; Accepted: 3 June 2016; Published: 14 June 2016

\begin{abstract}
Although the mapping of spatiotemporal patterns of urban expansion has been widely studied, relatively little attention has been paid to detailed comparative studies on spatiotemporal patterns of urban growth at the regional level over a relatively longer timeframe. This paper was based on multi-sensor remote sensing image data and employs several landscape metrics and the centroid shift model to conduct a multi-angle quantitative analysis on urban expansion in Beijing, Tianjin and Tangshan (Jing-Jin-Tang) in the period from 1970-2013. In addition, the impact analysis of urban growth on land use was adopted in this research. The results showed that Beijing, Tianjin and Tangshan all experienced rapid urbanization, with an average annual urban growth rate of $7.28 \%$, $3.9 \%$, and $0.97 \%$, respectively. Beijing has especially presented a single choropleth map pattern, whereas Tianjin and Tangshan have presented a double surface network pattern in orientation analysis. Furthermore, urban expansion in Beijing was mainly concentrated in Ring 4 to Ring 6 in the northwest and southeast directions, whereas the major expansion was observed in the southeast in Tianjin, primarily affected by dramatic development of Binhai New Area and Tianjin South Railway Station. Naturally, the urban expansion in Tangshan was significantly influenced by the expansion of Beijing and was primarily southwestward. The hot-zones of urbanization were observed within the ranges of $7-25 \mathrm{~km}, 6-18 \mathrm{~km}$, and $0-15 \mathrm{~km}$, accounting for $93.49 \%, 89.44 \%$ and $72.44 \%$ of the total expansion area in Beijing, Tianjin and Tangshan, respectively. The majority of the newly developed urban land was converted from cultivated land and integrated from other built-up land over the past four decades. Of all new urban land in the Beijing, Tianjin and Tangshan, more than 50\% was converted from cultivated land, and there was a general tendency for smaller cities to have higher percentages of converted land, accounting for $50.84 \%, 51.19 \%$, and $51.58 \%$, respectively. The study revealed significant details of the temporal and spatial distributions of urban expansion in Beijing, Tianjin and Tangshan and provided scientific support for the collaborative development of the Beijing, Tianjin and Hebei (Jing-Jin-Ji) regions.
\end{abstract}

Keywords: urban expansion; main urban area; spatiotemporal patterns; Jing-Jin-Ji Urban Agglomeration; Jing-Jin-Tang urban group

\section{Introduction}

Unprecedented urbanization, characterized by demographic shifts from rural to urbanized areas and urban land expansion, has taken place globally in the past several decades [1-3]. Although accounting for only a tiny proportion (perhaps less than $1 \%$ ) of the world's land surface, urban areas serve as a base of more than $90 \%$ of the global economy and $50 \%$ of the world's population $[4,5]$. Information on urban areas (or impervious surfaces) and their changes in time have significant 
implications in studies of urban growth modeling [6,7]. Urbanization is perhaps one of the most important human activities, creating enormous impacts on the environment at the local, regional and global scales [8]. Urban sprawl, a consequence of socioeconomic development under certain circumstances, has increasingly become a major issue that many metropolitan areas face $[9,10]$. Although a general consensus regarding the definition and impact of urban sprawl has not been achieved [11], urban sprawl is often considered uncontrolled, scattered suburban development that increases traffic problems, depletes local resources, and destroys open space [12]. The environmental impacts of the landscape changes resulting from urbanization are significant $[13,14]$. Scientists have paid increasing attention to urban expansion and consequential impervious surface growth and their impacts on biogeochemical cycles and biological diversity at local, regional and global scales [15]. Some of the problems associated with urban expansion include climate change [16-20], arable land loss [21], wetland destruction [22,23] and air and water pollution [24]. These problems lead to a reduced quality of life in both urban and rural societies [25]. Changes in urban settlements have distinctive patterns and properties that vary by city; therefore, it is necessary to find effective descriptors of urban settlements for specific research areas [26]. Thus, it is critically important to properly characterize urban sprawl before developing a comprehensive understanding of the causes and effects of urbanization processes in diverse areas such as urban planning, water and land resource management, marketing analysis, and service allocation $[9,27]$.

In the nearly four decades since China's Reform and Opening Up, the pace of urbanization has increased significantly [28]. China is undergoing a major transformation of its urban structure because of its rapid economic and population growth. It is critically important to properly characterize urban expansion before developing a comprehensive understanding of urbanization processes [29].

Dynamic urban expansion simulation at the regional scale is one of the important research methodologies in Land Use and Cover Change (LUCC) and global environmental change influenced by urbanization [30]. Followed by the Yangtze River, Jing-Jin-Ji Urban Agglomeration has become China's economic growth in the third pole. As the focus of northern economic development, it plays an important strategic role in China's politics and economic development [31].

Since the implementation of reform and open policy, these cities have experienced rapid and high-intensity development; science and technology parks, economic and industrial parks and other new development zones are especially emerging. The metropolitan cities present "spread" and "aggressive" expansion accompanied by regional urban development and megalopolis formation, resulting in increasing tension between urban rapid expansion and water and land resources [32,33]. The accurate prediction of urban expansion of the metropolitan area will provide an important reference to the alleviation of this contradiction.

This article aims to compare spatiotemporal patterns and the effects of the urbanization of Beijing, Tianjin and Tangshan in the past four decades and conduct a quantitative analysis of urban expansion from the regional landscape to the city and within city levels. The article also aims to use further qualitative analyses based on the LUCC data and its effect on land use to identify the coupling relationships of social, economic, political and spatial factors by urban growth. More concretely, the objectives of this study were to (1) dynamically map the locations and extents of the main urban area expansion; (2) access the amount and distribution of expansion area; (3) analyze the similarities and differences of general trends of urbanization, spatially explicit urban growth patterns, and spatial-temporal change of landscape metrics; (4) reveal the impact of the expansion of the main urban area on other land uses; and (5) expound the gravitation of spatial expansion among cities. It is of great significance to examine detailed spatiotemporal patterns of urban expansion at a regional level over a relatively long timeframe. Furthermore, the results of this study also offer a scientific decision-making platform for achieving the goals of macro-control, town planning, land management in government eco-environment protection and promoting healthy urbanization in the Beijing-Tianjin-Hebei region. 


\section{Materials and Methods}

\subsection{Study Area}

Followed by the Yangtze River Delta and Pearl River Delta city groups, the Jing-Jin-Ji Urban Agglomeration area has become China's center of economic growth in the third pole [31,34,35]. The Jing-Jin-Ji metropolitan area located in the eastern part of the North China Plain belongs to the Bohai Rim and consists of 13 cities (see Figure 1a,b). This urban group accommodates an urban population of approximately 30 million with a GDP of 4.8 trillion Yuan in the year 2013 [31]. Our study areas are the three main cities of the Jing-Jin-Ji Urban Agglomeration-Beijing, Tianjin and Tangshan (Figure 1c), which have also have long been known as the Golden Delta, Jing-Jin-Tang (Figure 1b). Beijing and Tianjin are two municipalities under direct administration of the Central Government, both surrounded by Hebei province. Beijing, with a city history of more than 3000 years and a capital history of more than 800 years, is the capital of contemporary China and the political and cultural center of the whole country. As the political, cultural and international communication center of China, Beijing has undergone relatively modest expansion since 1949. This expansion accelerated after the economic reforms in 1978. It has since experienced rapid population growth, economic increase and landscape alteration. The expansion of the urban area in Beijing has drawn substantial attention [36-41]. Tianjin, bordering Beijing approximately $130 \mathrm{~km}$ to the southeast, is the largest open port city and economic center in northern China. In 2009, three coastal districts (Hangu, Tanggu and Dagang) of Tianjin were formed into Binhai New Area, which is considered the third pole of Chinese economic development. Tangshan, located in the central zone of Bohai Bay, within approximately $150 \mathrm{~km}$ to the southeast of Beijing and $120 \mathrm{~km}$ to the northeast of Tianjin, has been a heavy industrial city for one hundred years. As a heavy industrial base, industry plays an important role in Tangshan's economic development. The urban growth and post-earthquake reconstruction in Tanghan drew much concern [42-44]. With the rapid development of high-speed trains, the distance among the three cities has grown much smaller (only 30-60 min travel by high-speed railway).

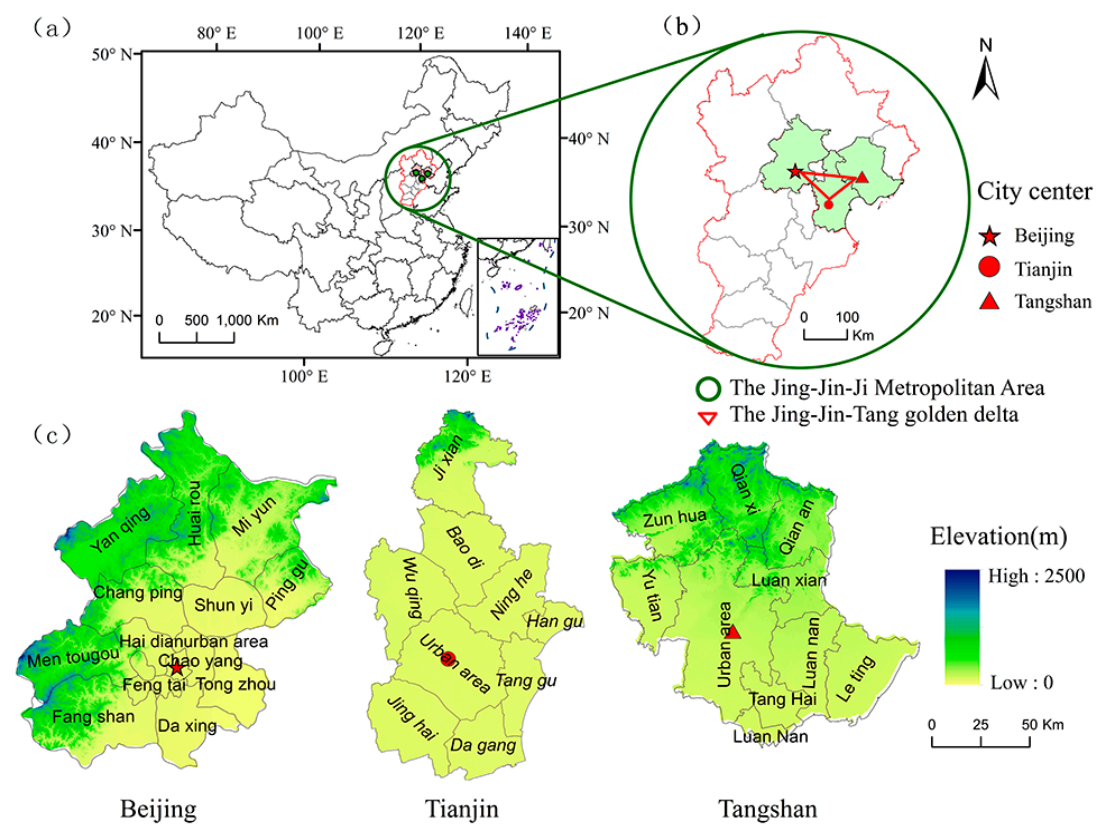

Figure 1. The location and administrative division of the study area-Beijing, Tianjin and Tangshan. (a) The study area in China; (b) The study area in the Jing-Jin-Ji Metropolitan area; (c) Topography and city center (the place of the municipal government) of Beijing, Tianjin and Tangshan. 
This study adopted the main urban area to compare the urban expansion in Beijing, Tianjin, and Tangshan because such an area is more similar to the urban entity region. A main urban area is a continuous region that has actually been developed and constructed and has basic public municipal facilities and public infrastructure facilities [45]. It can fully reflect cities as regions with high-density populations and various non-agricultural activities. In the process of cartography, the connectivity of the geographic space is fully considered, and it shows that the independent urban land areas around the cities are not converted. This may include two cases: one type includes the suburban areas, and the other features areas of industrial, mining, transportation and other enterprises and institution separated from the main urban districts.

\subsection{Data Sources}

Fifty-five multi-sensor remote sensing images covering the main urban area in the Jing-Jin-Tang metropolitan area were obtained from 1970 to 2013 (Table 1) from the following sources: Landsat 4 and Landsat 5 Multi-spectral Scanner (MSS), Landsat 5 Thematic Mapper (TM), Landsat 7 Enhanced Thematic Mapper Plus (ETM+), and Landsat 8 Operational Land Image (OLI) from the US Geological Survey (USGS) and China-Brazil Earth Resources Satellite (CBERS) Charge-coupled Device (CCD), and Environmental Satellite (HJ-1) CCD from the China Center for Resources Satellite Data and Application (CCRSDA). The images from mid-July to mid-August were chosen for better land cover detection during the vegetation growth season peak [46]. Landsat TM/ETM+/OLI images were the main remote sensing data source used in this study, accounting for approximately $75 \%$ of the images used, and Landsat MSS, CBERS CCD, and HJ-1 CCD data were used as alternative to fill gaps where Landsat TM images were poor in quality or unavailable. Because remote sensing data were scarce in the 1970s, the starting time for urban growth monitoring of the three cities could not be unified. In the 1970s, China was in a downturn of urban development, so the different starting times have a negligible impact on the following studies. An "area of interest" (AOI) boundary representing the metropolitan study area was delineated for the remote sensing analysis. The city and county boundary datasets were obtained from the Data Center for Resources and Environmental Sciences, Chinese Academy of Sciences (RESDC). Other assisted data to measure the impact of the urban extent were collected from the website of the National Bureau of Statistics of China (NBSC, http:/ / data.stats.gov.cn/) and were provided by the China Urban-Rural Construction Statistical Yearbook.

Table 1. Data types and monitoring times of Beijing, Tianjin and Tangshan used in this study.

\begin{tabular}{|c|c|c|c|c|c|}
\hline City & MSS & TM and ETM+ & CBERS CCD & HJ-1 CCD & OLI \\
\hline Beijing & $\begin{array}{l}1973 \\
1975 \\
1978\end{array}$ & $\begin{array}{l}1984,1987,1992,1996,1998,1999 \\
2000,2001,2002,2003,2004,2005 \\
2006,2007,2009,2010,2011\end{array}$ & 2008 & 2012 & 2013 \\
\hline Tianjin & $\begin{array}{l}1978 \\
1979\end{array}$ & $\begin{array}{l}\text { 1987, 1993, 1996, 1998, 2000, 2001, } \\
\text { 2004, 2006, 2009, } 2010\end{array}$ & 2008 & $\begin{array}{l}2011 \\
2012\end{array}$ & 2013 \\
\hline Tangshan & $\begin{array}{l}1976 \\
1979\end{array}$ & $\begin{array}{c}1987,1996,1998,1999,2000,2002 \\
2004,2006,2008,2009,2010\end{array}$ & - & $\begin{array}{l}2011 \\
2012\end{array}$ & 2013 \\
\hline
\end{tabular}

\subsection{Data Processing}

Because of the complexity of LUCC and its related research, there is no uniform classification system that is accepted by most scientists [47,48]. The LUCC classification system of the National Land-Use/Cover Database of China (NLUD-C) [49] was adopted to extract urban expansion information and its influences on local land use. The classification system contains two level types: the first-level types include cultivated land, woodland, grassland, built-up land, water bodies, and unused land, and the second-level types is more detailed types expression of the first level (Table 2). In this research, the main urban area is the study subject, which belongs to the built-up land of the first-level. 
Table 2. The land use/cover classification system.

\begin{tabular}{|c|c|c|}
\hline First Level Types & Second Level Types & Descriptions \\
\hline \multirow{2}{*}{ Cultivated land } & Paddy & $\begin{array}{l}\text { Cropland that has sufficient water supply and irrigation facilities for } \\
\text { planting paddy rice, lotus, etc., including land that is rotated for paddy } \\
\text { field rice and dry-farming crops }\end{array}$ \\
\hline & Dry land & $\begin{array}{l}\text { Cropland for cultivation without water supply and irrigation facilities; } \\
\text { cropland that has water supply and irrigation facilities and planting dry } \\
\text { farming crops; cropland planting vegetables; fallow land. }\end{array}$ \\
\hline \multirow{4}{*}{ Woodland } & Forest & Natural or planted forests with canopy cover greater than 30\% \\
\hline & Shrub & $\begin{array}{l}\text { Land covered by trees less than } 2 \mathrm{~m} \text { in height, with canopy cover } \\
\text { greater than } 40 \%\end{array}$ \\
\hline & Sparse woods & Land covered by trees with canopy cover of $10 \%-30 \%$. \\
\hline & Other woods & Land such as tea gardens, orchards, groves and nurseries. \\
\hline \multirow{3}{*}{ Grassland } & Dense grass & Grassland with canopy cover greater than $50 \%$ \\
\hline & Moderate grass & Grassland with canopy cover of $20 \%$ and $50 \%$ \\
\hline & Sparse grass & Grassland with canopy cover of $5 \%$ and $20 \%$ \\
\hline \multirow{6}{*}{ Water bodies } & River and canal & Land covered by rivers, including canals \\
\hline & Lake & Land covered by lakes \\
\hline & Reservoir and pond & Man-made facilities for water reservation \\
\hline & Ice and snow & Land covered by perennial snowfields and glaciers \\
\hline & Tidal flat & Land between high-tide level and low-tide level \\
\hline & Bottomland & Land between normal water level and flood level \\
\hline \multirow{3}{*}{ Built-up land } & Urban & Land used for urban settlement \\
\hline & Rural settlement & Land used for village settlements \\
\hline & Industry-traffic land & $\begin{array}{l}\text { Land used for factories, quarries, mining, oil-field slattern outside cities } \\
\text { and land for special uses, such as transportation and airports }\end{array}$ \\
\hline \multirow{7}{*}{ Unused land } & Sandy land & Sandy land covered with less than $5 \%$ vegetation cover \\
\hline & Gobi & Gravel-covered land with less than $5 \%$ vegetation cover \\
\hline & Saline-alkali land & Land with saline and alkali accumulation and sparse vegetation \\
\hline & Swampland & $\begin{array}{l}\text { Land with a permanent mixture of water and herbaceous or woody } \\
\text { vegetation that covers extensive areas }\end{array}$ \\
\hline & Bare soil & Bare exposed soil with less than $5 \%$ vegetation cover \\
\hline & Bare rock & Bare exposed rock with less than $5 \%$ vegetation cover \\
\hline & Other & Other land types such as alpine desert and tundra \\
\hline
\end{tabular}

Image pre-processing and classification were performed using ERDAS IMAGINE 9.2 (Leica, Inc., Atlanta, GA, USA), Arc GIS 10.0 (ESRI, Inc., RedLands, CA, USA) and Modular GIS Environment 7.01 (MGE; Intergraph, Inc., Madison, WI, USA). To meet visual interpretation needs, and avoid the effect of processing methods on the color and texture features of images, various image processing methods were not adopted before interpretation unless the quality of image is poor, [49,50]. We emphasized geometric rectification to ensure that an urban area in different remote sensing images has the same geographical location. All purchased images were rectified and georeferenced to the Albers projection system based on 1:100,000 topographic maps of China. We conducted image-to-image registration of all images to the master scene. Geometric rectification of the image set using ground control points was manually performed. The total root mean square error obtained for the ground control points did not exceed 0.5 pixels. All data were composited using standard false-color synthesis. Finally, visual interpretation based on professional knowledge and experience, focusing on the applications and extraction of accurate information to retrieve the entire urban expansion process [49], was used to monitor urban expansion and its impact on local land use. On the Intergraph MGE platform, based on the established interpretation symbols of urban land, researchers with experience in visual interpretation referred to Google Earth and topographic maps to adopt the human-computer 
interactional digital interpretation method and extract the boundary line of urban land in the initial phase remote sensing image. On this basis, change information by image-to-image comparison was drawn as dynamic pattern spots and given attributes. To ensure the accuracy of the attributes of change patterns, field survey records, landscape photographs, and auxiliary data were adopted in this study. At the same time, the boundary line of urban land and the dynamic spots of land use are guaranteed to be close. To track urban growth, it is important to have accurate urban area maps in multiple years. We refer to the drawing standard of NLUD-C to ensure accuracy of the monitoring results above $90 \%[48,51]$.

\subsection{Methods}

\subsubsection{Division of Urban Expansion Directions and Zones}

The direction and buffer zone of the outward urban expansion from the city center were drawn by ArcGIS 10.0. Rays extending from the city center were drawn with equal intervals of $45^{\circ}$ from the north in the clockwise direction, resulted in a total of 8 fans of land expansion (N, NE, E, SE, S, SW, W, NW). The buffer zones were generated and overlaid with the new urban growth polygons at regular intervals of $1000 \mathrm{~m}$ (Figures 2-4). The area of the new urban growth land in each buffering was extracted at all monitoring stages.

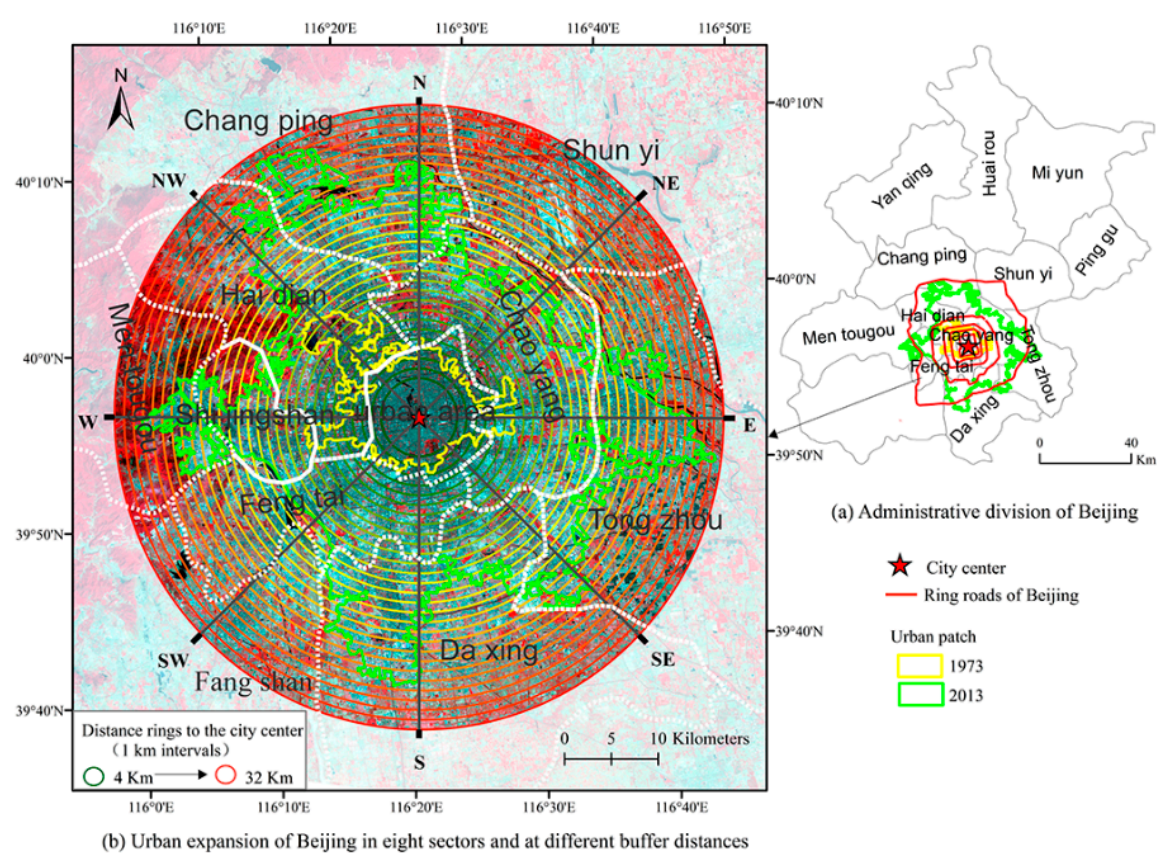

Figure 2. Urban expansion of Beijing in eight sectors and at different distances from the city center from 1973 to 2013. (a) Administrative division and the main Ring road of Beijing; (b) Urban expansion of Beijing in eight sectors and different buffer distances. 


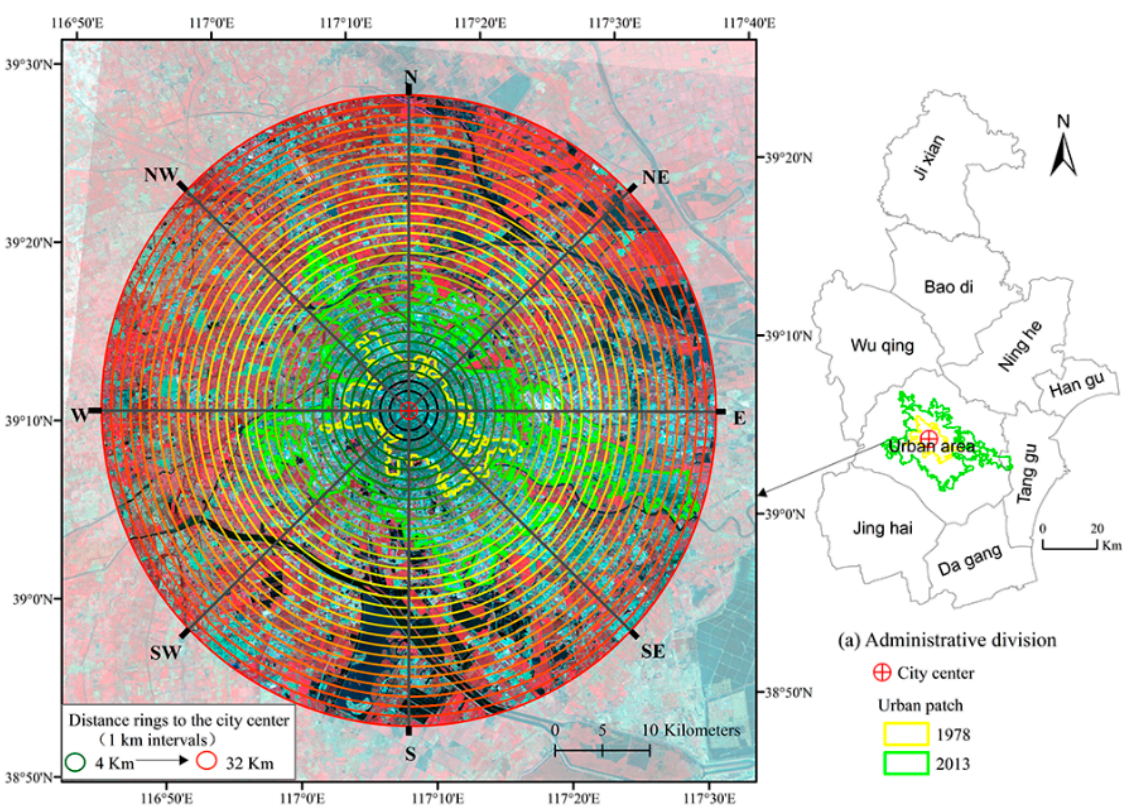

(b) Urban expansion of Tianjin in eight sectors and at different buffer distances

Figure 3. Urban expansion of Tianjin in eight sectors and at different distances from the city center from 1978 to 2013. (a) Administrative division and of Tianjin; (b) Urban expansion of Tianjin in eight sectors and different buffer distances.

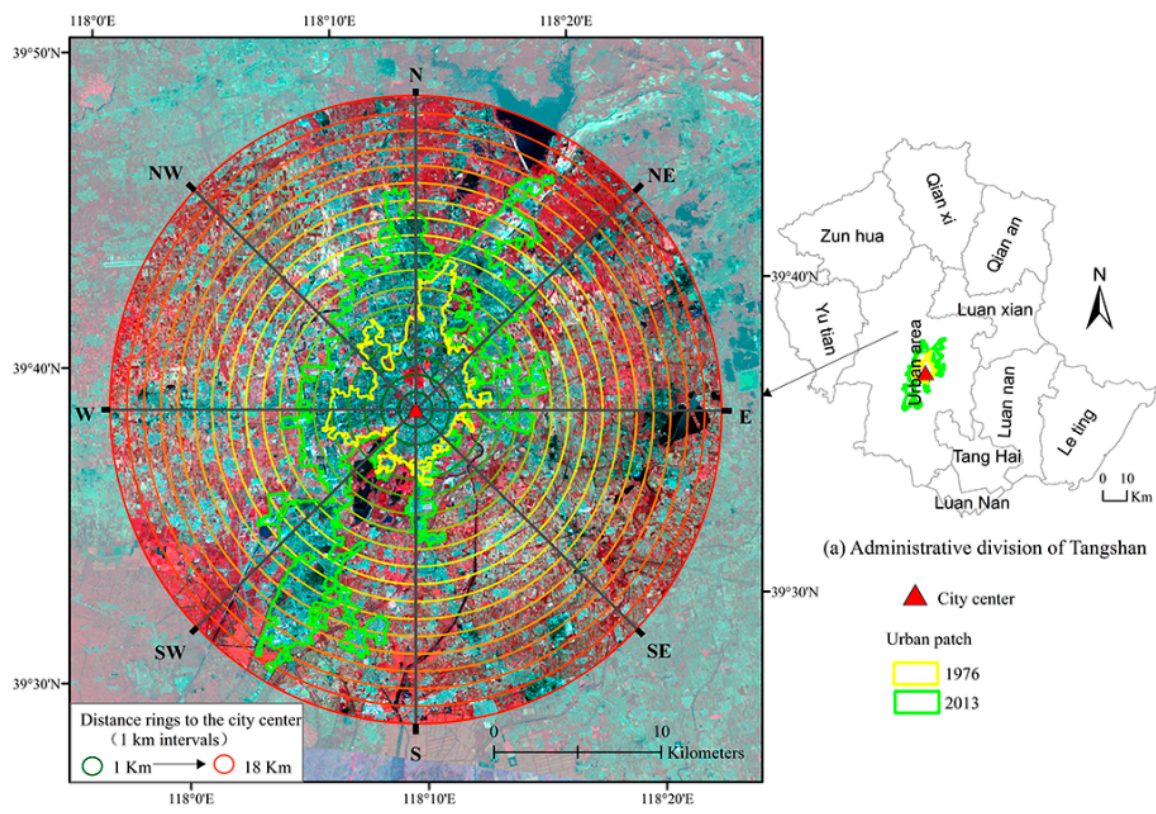

(b) Urban expansion of Tangshan in eight sectors and at different buffer distance

Figure 4. Urban expansion of Tangshan in eight sectors and at different distances from the city center from 1976 to 2013. (a) Administrative division and of Tangshan; (b) Urban expansion of Tangshan in eight sectors and different buffer distances. 


\subsubsection{Landscape Metrics Analyzed}

Landscape metrics provide a quantitative description of the composition and configuration of urban landscapes. These metrics were computed for the main urban land expansion of each city at the landscape level with the help of FRAGSTATS 4.2 [52] with the eight-neighbor rule. For the objectives of this study and to avoid redundancy, land expansion is characterized by three prominent spatial metrics chosen based on spatial and complexity criteria. Overall changes in urban patterns were analyzed using several landscape metrics: percentage of landscape (PLAND), landscape shape index (LSI), and normalized landscape shape index (Table 3).

Table 3. Landscape metrics analyzed.

\begin{tabular}{|c|c|c|c|}
\hline Acronym & $\begin{array}{c}\text { Name of } \\
\text { Landscape Metric } \\
\text { (units) }\end{array}$ & Equation & Description \\
\hline PLAND & $\begin{array}{l}\text { Percentage of } \\
\text { Landscape (\%) }\end{array}$ & $\begin{array}{c}\text { PLAND }=\mathrm{P}_{i}=\frac{\sum_{j=1}^{n} a_{i j}}{A}(100) \\
\left(\mathrm{P}_{i}=\text { proportion of the landscape occupied by patch type } \mathrm{i} ;\right. \\
\left.\mathrm{a}_{i j}=\text { area }\left(\mathrm{m}^{2}\right) \text { of patch } \mathrm{ij} ; \mathrm{A}=\text { total landscape area }\left(\mathrm{m}^{2}\right)\right)\end{array}$ & $\begin{array}{l}\text { The percentage the } \\
\text { landscape of the } \\
\text { corresponding } \\
\text { patch type. }\end{array}$ \\
\hline LSI & $\begin{array}{l}\text { Landscape Shape } \\
\text { Index }\end{array}$ & $\begin{array}{c}\mathrm{LSI}=\frac{0.25 \sum_{k=1}^{m} e_{i k}^{*}}{\sqrt{A}} \\
\left(e_{i k}^{*}=\text { total length of edge }(\mathrm{m}) \text { between patch } \mathrm{i} \text { and } \mathrm{k} ;\right. \\
\left.\mathrm{A}=\text { total landscape area }\left(\mathrm{m}^{2}\right)\right)\end{array}$ & $\begin{array}{l}\text { Provides a standardized } \\
\text { measure of total edge or } \\
\text { edge density that adjusts } \\
\text { for the size of } \\
\text { the landscape. }\end{array}$ \\
\hline NLSI & $\begin{array}{l}\text { Normalized } \\
\text { Landscape } \\
\text { Shape Index }\end{array}$ & $\begin{array}{c}\text { NLSI }=\frac{\sum_{i=1}^{i=N} \frac{p_{i}}{N}}{N} \\
\left(p_{i} \text { and } S_{i} \text { are the perimeter and area of patch } \mathrm{i},\right. \\
\text { and N is the total number of patches) }\end{array}$ & $\begin{array}{l}\text { It essentially measures } \\
\text { the degree } \\
\text { of aggregation. }\end{array}$ \\
\hline
\end{tabular}

Generally, the PLAND quantifies the proportional abundance of each patch type in the landscape; it approaches 0 when the corresponding patch type becomes increasingly rare in the landscape, and it equal to 100 when the entire landscape consists of a single patch type. The LSI measures the perimeter-to-area ratio for the landscape as a whole, which is identical to the habitat diversity index. LSI $=1$ when the landscape consists of a single square patch of the corresponding type, and it increases without limit as the landscape shape becomes more irregular. NLSI is 0 when the landscape consists of a single square or maximally compact almost square; it increases as patch types become increasingly disaggregated and is 1 when the patch type is maximally disaggregated.

\subsubsection{Centroid Shift and Space Gravity Models}

To obtain a quantitative and intuitive description of the spatial change characteristics of urban expansion in the Jing-Jin-Tang city group from the 1970s to 2013, the centroid shift model was employed in this study [53]. The equation for the model is given as follows:

$$
\begin{aligned}
& X_{t}=\sum_{i=1}^{n}\left(C_{t i} \times X_{i}\right) / \sum_{i=1}^{n} C_{t i} \\
& Y_{\mathbf{t}}=\sum_{i=1}^{n}\left(C_{t i} \times Y_{i}\right) / \sum_{i=1}^{n} C_{t i}
\end{aligned}
$$

where $X_{t}$ and $Y_{t}$ indicate the area-weighted abscissa and ordinate of all urban patches in year $t$, respectively; $C_{t i}$ is the area of urban land patch $i$ in the $t$ th year, $\mathrm{n}$ is the total number of patches of urban land, and $X_{i}$ and $Y_{i}$ are the abscissa and ordinate of urban land patch $i$, respectively.

To describe the amplitude of the centroid shift, the distance $\mathrm{D}$ is defined as

$$
D=\sqrt{\left(X\left(t_{2}\right)-X\left(t_{1}\right)\right)^{2}+\left(Y\left(t_{2}\right)-Y\left(t_{1}\right)\right)^{2}}
$$


where $D(\mathrm{~m})$ is the distance of the centroid shift; $X\left(\mathrm{t}_{1}\right), Y\left(\mathrm{t}_{1}\right), X\left(\mathrm{t}_{2}\right)$, and $Y\left(\mathrm{t}_{2}\right)$ are the area-weighted abscissa and ordinate of all urban land patches in years $t_{1}$ and $t_{2}$, respectively; $t_{1}$ is the beginning of the monitoring period; and $t_{2}$ is the end of the monitoring period.

Gravity models are the most widely used types of interaction models [54]. They are mathematical formulations that are used to analyze and forecast spatial interaction patterns. The gravity model, which derives its name from an analogy to the gravitational interaction between planetary bodies, appears to capture and interrelate at least two basic elements: (1) scale impacts: for example, cities with large area tend to generate and attract more activities than cities with small areas; and (2) distance impacts: for example, the farther places, activities are apart, the less they interact. To account for the interactions between cities, this paper induces the modified Newton's law of universal gravitation. In the law, each body attracts every other body with a force that is proportional to its mass. The gravitational force between cities is a relative value, but it can reflect the close relationship between cities at a certain level. The greater the value of gravity, indicating a closer relationship between the city. Here, the mass of the body is replaced by the urban area, and the distance is the centroid between two cities. $G$ is a constant coefficient. The equation for the model is given as follows:

$$
F=G \frac{A_{i} \times B_{i}}{R_{i}}
$$

where

$F$ is the relative interaction between two cities;

$G$ is a constant coefficient;

$A_{i}$ is the area of city $\mathrm{A}$ in year $i$;

$B_{i}$ is the area of city $\mathrm{B}$ in year $i$;

$R_{i}$ is the distance between the centroids of the two cities in year $i$.

\section{Results}

\subsection{Urban Land Dynamic Change}

\subsubsection{Quantitative Analysis of Urban Expansion}

Over the past four decades, Beijing, Tianjin and Tangshan have undergone rapid urbanization (Figure 5), which can be seen from the continuous expansion of their urban land, and the area of the three cities has increased by $1152.84 \mathrm{~km}^{2}, 467.22 \mathrm{~km}^{2}$, and $98.71 \mathrm{~km}^{2}$, respectively.

For Beijing; remote sensing monitoring of the main urban area started in 1973 and ended in 2013; totaling 23 periodic images. The Beijing main urban district extended in the form of the "pie" type and had obvious differences among periods: the rate of expansion was slow at $7.83 \mathrm{~km}^{2}$ per year in the period from 1973 to 1987; in the late 1980s; the increasing demand for urban land; under the effect of the policy of reform and opening up in China; resulted in an annual average rate of urban expansion of $37.24 \mathrm{~km}^{2}$ during 1987-1998; affected by the Asian financial crisis; the expansion significantly slowed down in the late 1990s; during 2000-2003; the average annual expansion reached the pinnacle; $83.19 \mathrm{~km}^{2}$; whereas the expansion speed slowed down again during 2003-2013. During 1987-1998 and 1998-2003; urban expansion was relatively faster than in the other periods; and the new expansion region area accounted for more than half the total extension area in the two periods. 


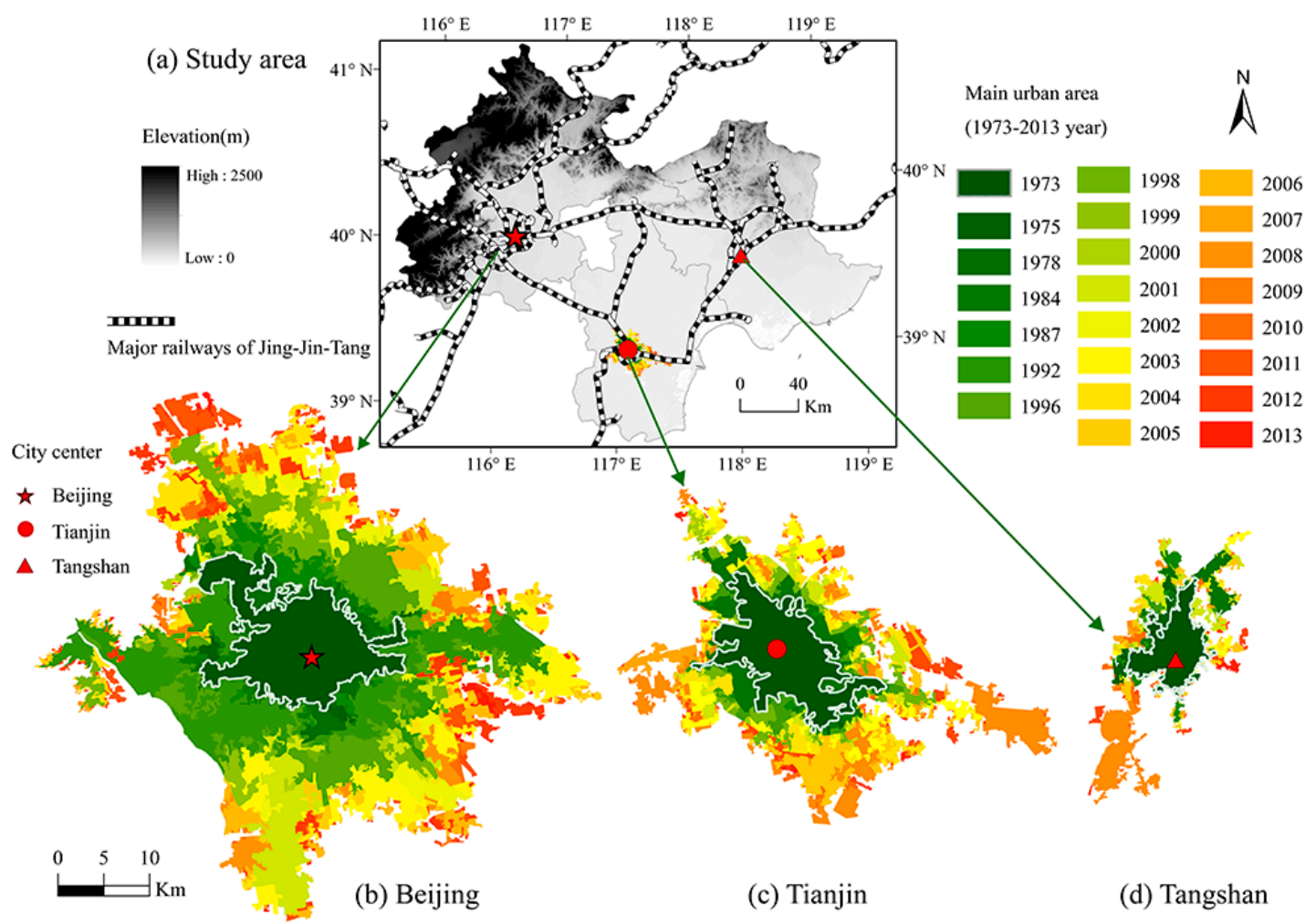

Figure 5. Sequences of long-term mapping of urban expansion patterns of Beijing, Tianjin and Tangshan, in China. (a) The study area of Jing-Jin-Tang; (b) Beijing; (c) Tianjin; (d) Tangshan.

For Tianjin, remote sensing monitoring of the main urban area started in 1978 and ended in 2013, totaling 16 sequential images. In the past 35 years, the main urban area has expanded along the Jing-Jin-Tang expressway, Tianjin port and other highways, and the rate of expansion has also presented differences in various periods: during 1978-1996, the main district established slowly at an average of $5.18 \mathrm{~km}^{2}$ around the old urban area; during 1996-2010, with the rapid social and economic development, the demand for urban land was increasing, and the extension area was $336.04 \mathrm{~km}^{2}$; after 2010, the rate and amplitude of expansion decreased, and the area increased by only $12.62 \mathrm{~km}^{2}$ annually, slightly less than average over the past 35 years.

As a "post-earthquake reconstruction" city, Tangshan is benefiting from proper reconstruction planning guidance and the radiative and exemplary role of Beijing and Tianjin. The remote sensing monitoring of its main urban area during 1976-2013 totaled 16 serial images. During those times, the main city area annually grew at a rate of approximately $2.67 \mathrm{~km}^{2}$. The Tangshan earthquake on 28 July 1978 seriously influenced the development of this city. During 1976-1996, this city underwent decelerating expansion along with accelerated urbanization, with the center urban area rapidly expanding at an average annual rate of $3.68 \mathrm{~km}^{2}$ during 1996-2002; during 2002-2009, it underwent undergone smooth expansion at the rate of $3.4 \mathrm{~km}^{2}$ per year; after 2009, the growth rate of the main urban area expansion decreased. In the rapid development of the Lunan district, Lubei district, and Kaiping district, the total urban areas are all increasing.

\subsubsection{Landscape Metrics for Urban Land Expansion}

Figure 6 demonstrates the features and trends of urban landscape change for the three cities from 1973 to 2013. As urbanization proceeded, the area and PLAND of the main city area showed a monotonic increasing trajectory; meanwhile, there is a much steeper trend for Beijing than that of Tianjin and Tangshan (Figure 6a,b). The urban PLAND increased from 1.12\% to 9.03\% for Beijing, 1.07\% to $5.05 \%$ for Tianjin, and $0.39 \%$ to $1.35 \%$ for Tangshan (Figure $6 \mathrm{~b}$ ). Before 1987, Tianjin was experiencing 
compact growth mode, while Beijing and Tangshan represented relatively decentralized expansion. During 1987-1996, the expansion mode of Tianjin and Tangshan were relatively compact and peaceful, however Beijing was experiencing dispersed growth before 1992, then shown a compact expansion. After 1996, All the cities revealed a continuous disaggregated expansion mode, besides, Tianjin was experiencing the most dispersed growth among the three cities (Figure 6c). Results (Figure 6d) indicate that the landscape of Tangshan was the most fragmented, and its NLSI was close to 1 . The landscapes of Beijing and Tianjin were relatively aggregated: in particular, the landscape of Tianjin was more irregular than Beijing's. Before 1987, the values of NLSI were continuing to rise in Tangshan, Tianjin's reversed the downward trend, and Beijing's had four waves trend. During 1987-1998, the peak occurred in 1998 for Beijing, whereas Tianjin and Tangshan underwent a gentle increase, followed by a great increase again for all cities after 1998. The results indicate that the landscape of Tangshan is much more fragmented than Beijing and Tianjin in all periods according to the metric of NLSI (Figure 6d).
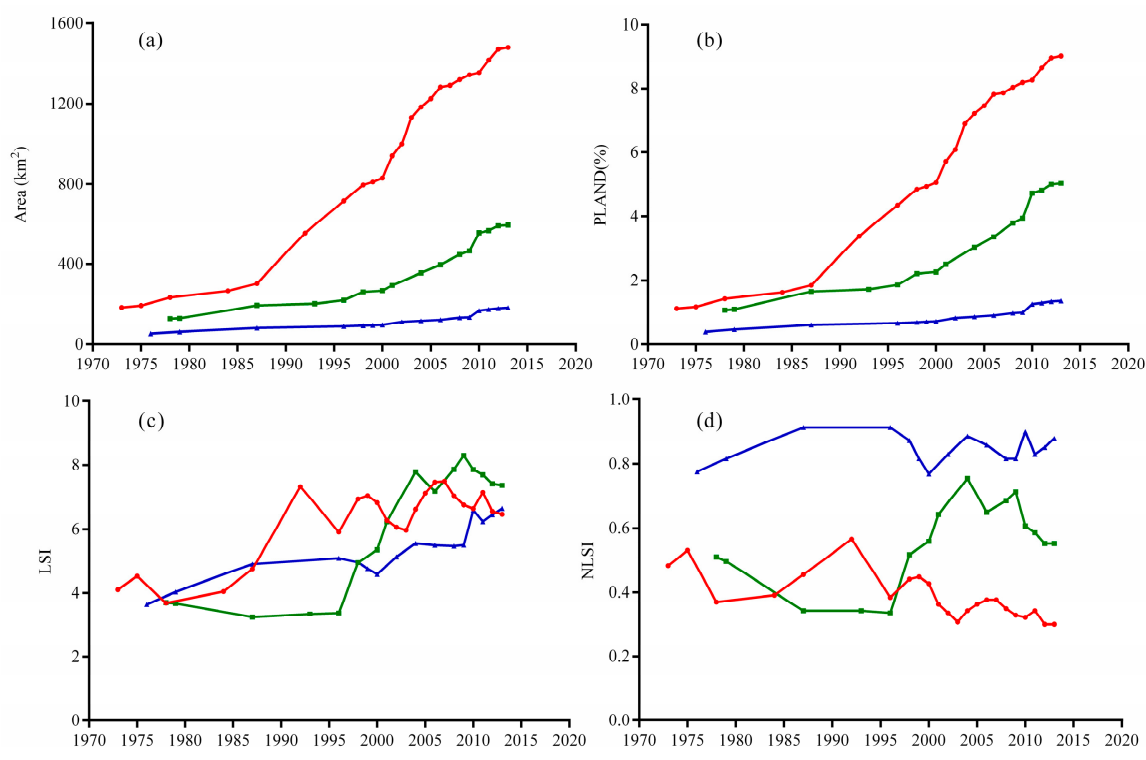

$$
\rightarrow \text { Beijing } \rightarrow \text { Tianjin } \rightarrow \text { Tangshan }
$$

Figure 6. Landscape metrics for the urban land of Beijing, Tianjin and Tangshan from the 1970s to 2013.

(a) Area $\left(\mathrm{km}^{2}\right)$; (b) PLAND (\%); (c) LSI; (d) NLSI.

\subsection{Spatiotemporal Pattern Analysis of Urban Expansion}

\subsubsection{The Centroid Shift of the Main Urban District}

The centroid of the city is one of the important parameters that indicate the direction and spatial pattern of urban expansion. Owing to differences in economic, demographic and terrain factors, the shift of the city centroid also shows great disparities (Figure 7). As the capital city of China, policy and terrain are the main factors influenced Beijing's spatial pattern. Because northwest of Beijing is the Taihang Mountains, Beijing expanded to the southeast, approximately $2.57 \mathrm{~km}$. As a port city, Tianjin moved towards the coastline, and the shift distance is $2.83 \mathrm{~km}$ to the southeast [53]. The centroid shift of Tangshan, which is under the immense influences of Beijing and Tianjin, is $1.02 \mathrm{~km}$ in the southwest direction. 


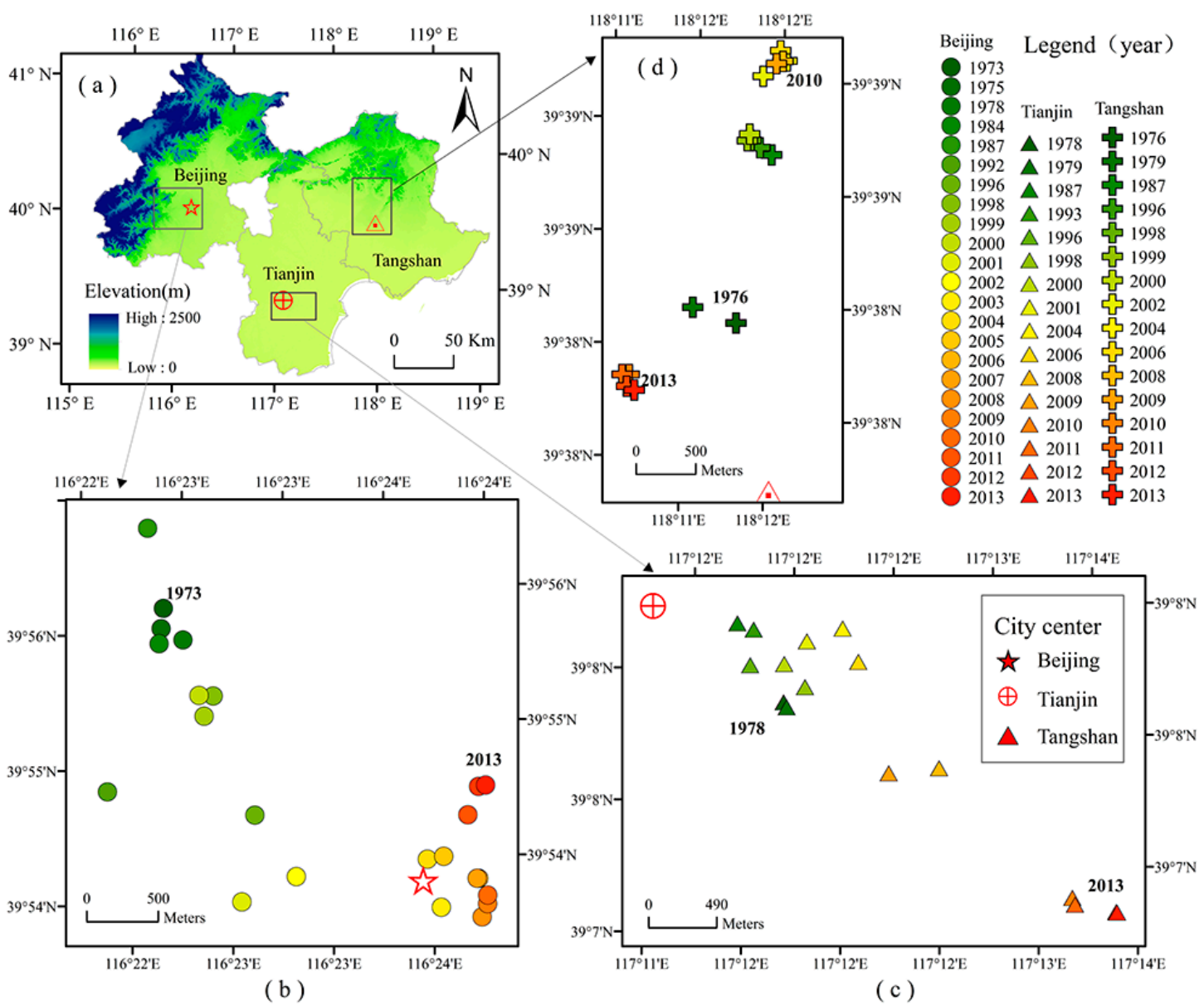

Figure 7. The displacement of the urban patch centroid in Beijing-Tianjin-Tangshan, from the 1970s to 2010s. (a) The study area of Beijing-Tianjin-Tangshan; (b) The shift of the urban patch centroid in Beijing from 1973 to 2013; (c) The shift of the urban patch centroid in Tianjin from 1978 to 2013; (d) The shift of the urban patch centroid in Tangshan from 1976 to 2013.

\subsubsection{The Spatial Orientation of Urban Land Expansion}

To further understand the detailed spatial patterns of the intra-city landscape, this study charted urban expansion in different directions with cumulative area (Figure 8, Table 4).

Specifically, for Beijing, the urban land expanding almost occurred in every direction from the original urban core, presented a single choropleth map pattern (Figure 9a), and the main expansion area occurred in the southeast (NE-E, E-SE, SE-S) in the clockwise direction, in which the urban expansion area increased by approximately $43.1 \%$, and the most drastic expansion was observed in NW-N, whose expansion area increased by approximately $19.7 \%$. There were two large-scale expansions during 1987-2003; the area increased by $20.2 \%$ during 1987-1992, which mainly occurred in the Fengtai region SW-W of Beijing, and the second period accounted for $10.9 \%$ growth in Chaoyang district, Tongzhou district and Daxing district from 2002 to 2003, which was consistent with the main expansion trend. 

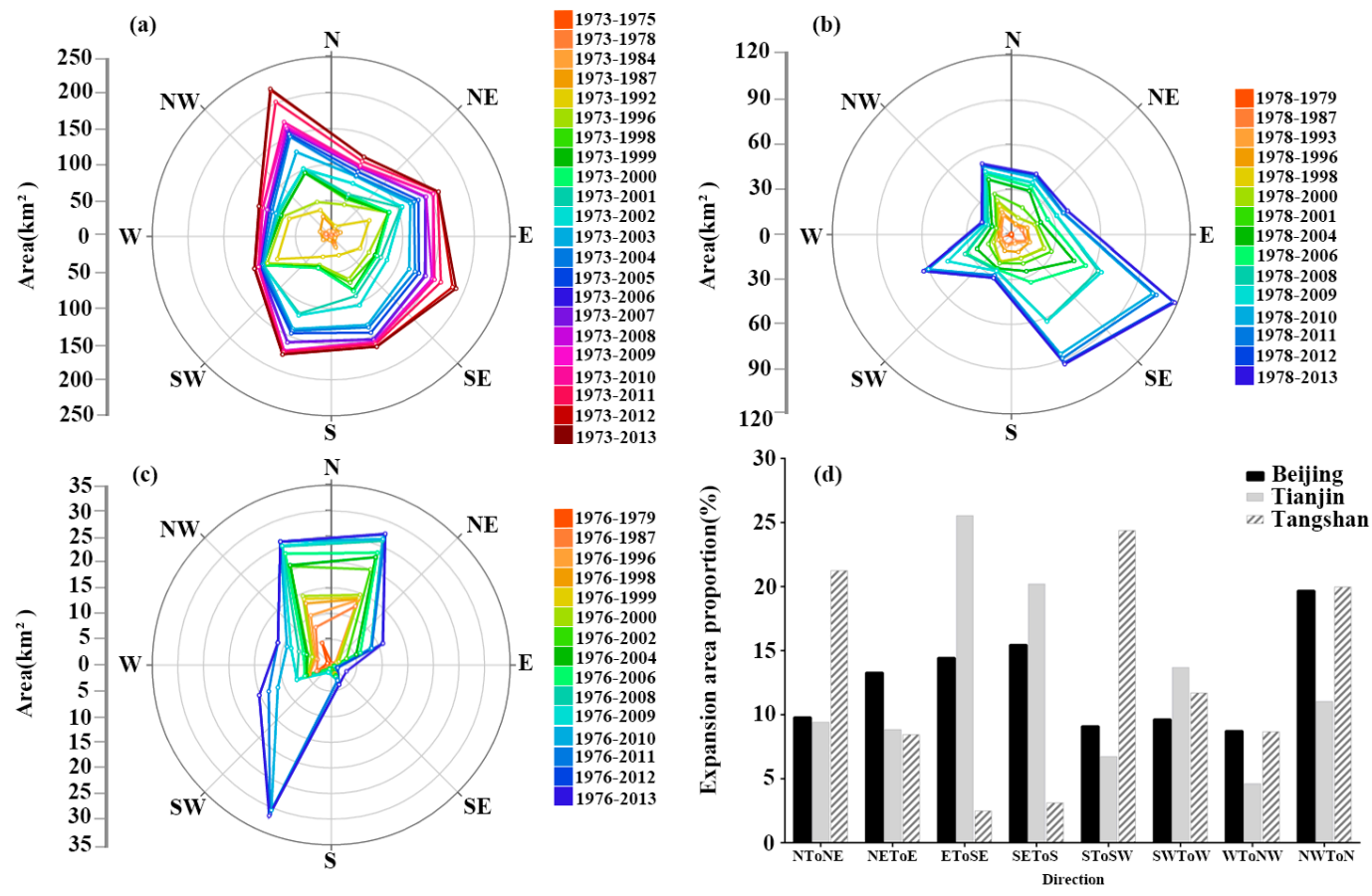

Figure 8. Spider diagrams of the urban expansion of Jing-Jin-Tang in eight sectors (N-NE, NE-E, E-SE, SE-S, S-SW, SW-W, W-NW and NW-N) from the 1970s to 2010s: (a) Beijing, (b) Tianjin, (c) Tangshan, (d) Expansion area proportion of the three cities.

Table 4. Proportion of urban land expansion along 8 directions in Jing-Jin-Tang, 1970-2013 (\%).

\begin{tabular}{lccc}
\hline Direction & Beijing & Tianjin & Tangshan \\
\hline N to NE & 9.78 & 9.41 & 21.24 \\
NE to E & 13.27 & 8.83 & 8.44 \\
E to SE & 15.44 & 25.53 & 2.49 \\
SE to S & 14.42 & 20.19 & 3.11 \\
S to SW & 9.09 & 6.72 & 24.38 \\
SW to W & 9.62 & 13.78 & 11.70 \\
W to NW & 8.72 & 4.61 & 8.77 \\
NW to N & 19.66 & 11.02 & 19.96 \\
\hline
\end{tabular}

For Tianjin, the main expansion occurred in the southeast (E-SE, SE-S) direction, in which the urban expansion area increased by approximately 45.7\% of the total expansion area from 1978 to 2013. Especially, affected by the rapid development of Binhai New Area, the largest expansion of $7.99 \%$ occurred during 2009-2010. Meanwhile, under the influence of the Tianjin South Railway Station construction, there was short, dramatic expansion in the southeast direction, which increased by $3.01 \%$. In the whole expansion process, it formed a double surface network pattern (Figure 9b).

For Tangshan, the urban expansion radar map shows a polarization trend from north to south, also represented double surface network pattern (Figure 9c), and the expansion proportion in the north direction was $41.1 \%$, whereas in the southwest it was $24.4 \%$. In the north direction, the largest-scale expansion occurred in Lubei district during 2000-2002, which increased by approximately 8.7\%. In particular, the largest-scale expansion occurred in Fengnan district from 2009 to 2013, which increased by almost $22.3 \%$ in the southwest direction.

\subsubsection{Hot-Zones of Urban Expansion}

Understanding the locations of the growth hot-zones is essential for urban growth and city design and planning. To avoid redundancy, the concentric circle analysis revealed that over the past 
four decades, Jing-Jin-Tang expanded outward in a layered structure (Figure 9). The main urban extension distance was similar in Beijing and Tianjin, forming an outline with an approximately $30 \mathrm{~km}$ radius, whereas the urban extension distance was only half of the former two cities in Tangshan (Figure 9a). However, the forms were slightly different: for Beijing, the entire extended area showed an approximately normal distribution, whereas the urban extension presented a skewed distribution in Tianjin and Tangshan. The hot-zones of urbanization of the three cities were observed within the ranges of $7-25 \mathrm{~km}, 6-18 \mathrm{~km}$, and $0-15 \mathrm{~km}$, accounting for $93.49 \%, 89.44 \%$ and $72.44 \%$ of the total expansion area, respectively. Especially for Beijing, the area in the ring was fully urbanized by 2013, which was approximately equivalent to the distance of Beijing Ring 5.
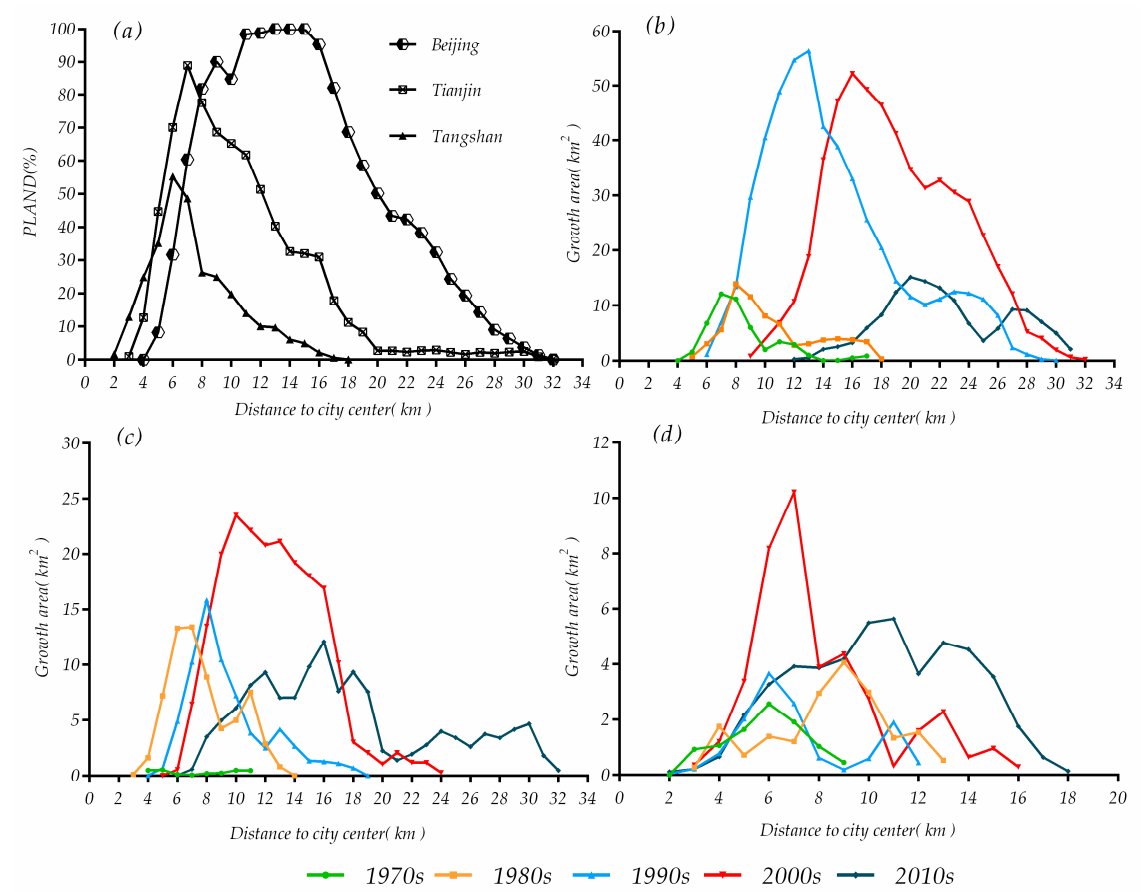

Figure 9. Area metrics for the urban expansion of Jing-Jin-Tang at different distance (with $1 \mathrm{~km}$ intervals), from the 1970s to 2010s: (a) PLAND(\%) of three cities; (b) Growth Area of Beijing; (c) Growth Area of Tianjin; (d) GrowArea of Tangshan.

For Beijing (Figure 9b), the total urban expansion area was approximately $1295 \mathrm{~km}^{2}$ with a distance between $4 \mathrm{~km}$ and $32 \mathrm{~km}$ from the 1970s to 2010s, and the per-period urban expansion area proportion was approximately $3.73 \%, 5.46 \%, 39.18 \%, 41.02 \%$ and $10.61 \%$ of the total growth area. The main expansion took place in the zones within a distance of $10 \mathrm{~km}$ to $20 \mathrm{~km}$ from the edge of the pre-growth urban patches during the 1990s and 2000s, respectively; $30.7 \%$ of the total expansion area in the $1990 \mathrm{~s}, 26.5 \%$ in the $2000 \mathrm{~s}$, and $42.8 \%$ in the other periods took place within a distance of $4-10 \mathrm{~km}$ and $20-32 \mathrm{~km}$ from the former urban fringe. Thus, the hot-zone of Beijing urban expansion is the buffer zone from $10 \mathrm{~km}$ to $20 \mathrm{~km}$. In other words, the fastest growth region of Beijing is from the fourth ring road to the sixth ring road, and according to the radar map of Beijing urban expansion, those regions were near Zhongguancun Park in Haidian district and Yizhuang Park in Daxing district.

For Tianjin (Figure 9c), the total urban expansion area was approximately $467 \mathrm{~km}^{2}$ with a distance between $2 \mathrm{~km}$ and $18 \mathrm{~km}$ from the 1970s to 2010s. Each period's urban expansion area proportion was approximately $0.55 \%, 13.89 \%, 14.31 \%, 43.49 \%$ and $27.76 \%$, and its main expansion took place in zones within a distance of $9 \mathrm{~km}$ to $16 \mathrm{~km}$ during the 2000s and 2010s; approximately $34.6 \%$ of the total growth area in the 2000s, $13.8 \%$ in the $2010 \mathrm{~s}$, and $42.6 \%$ in the other periods took place within a distance of 4-9 km and 16-32 km from the former urban fringe. Thus, the hot-zone of Tianjin urban expansion is the buffer zone from $9 \mathrm{~km}$ to $16 \mathrm{~km}$. During the 1990s and 2000s, the largest-scale change 
occurred; following the radar map result, this change led to the development of the Binhai New Area in the hot-zone from $9-16 \mathrm{~km}$ in the southeast of Tianjin.

For Tangshan (Figure 9d), the total urban expansion area was approximately $130 \mathrm{~km}^{2}$ with a distance between $2 \mathrm{~km}$ and $18 \mathrm{~km}$ from the 1970s to the 2010s. Each period's urban expansion area proportion was approximately $7.35 \%, 14.38 \%, 10.02 \%, 31.0 \%$ and $37.25 \%$, and the faster expansion took place in zones within a distance of $5 \mathrm{~km}$ to $9 \mathrm{~km}$ in the 2000s. During the 2000s and 2010s, there was also larger-scale expansion in the $11 \mathrm{~km}$ buffer zone, and according to the radar map of Tangshan, the Lubei district in the north of the city and the Fengnan district in the southwest direction were developing rapidly.

\subsection{The Impact on the Other Land Use}

Urban expansion is one part of LUCC, which is an event of paramount importance in the study on global environmental change. In the past four decades, the spatial expansion of Beijing, Tianjin and Tangshan influenced its social and economic development on the regional and national scales and profoundly affected the land use in Jing-Jin-Tang area. The majority of the newly developed urban land encroached on the cultivated land and other built-up land (Figure 10b-d).

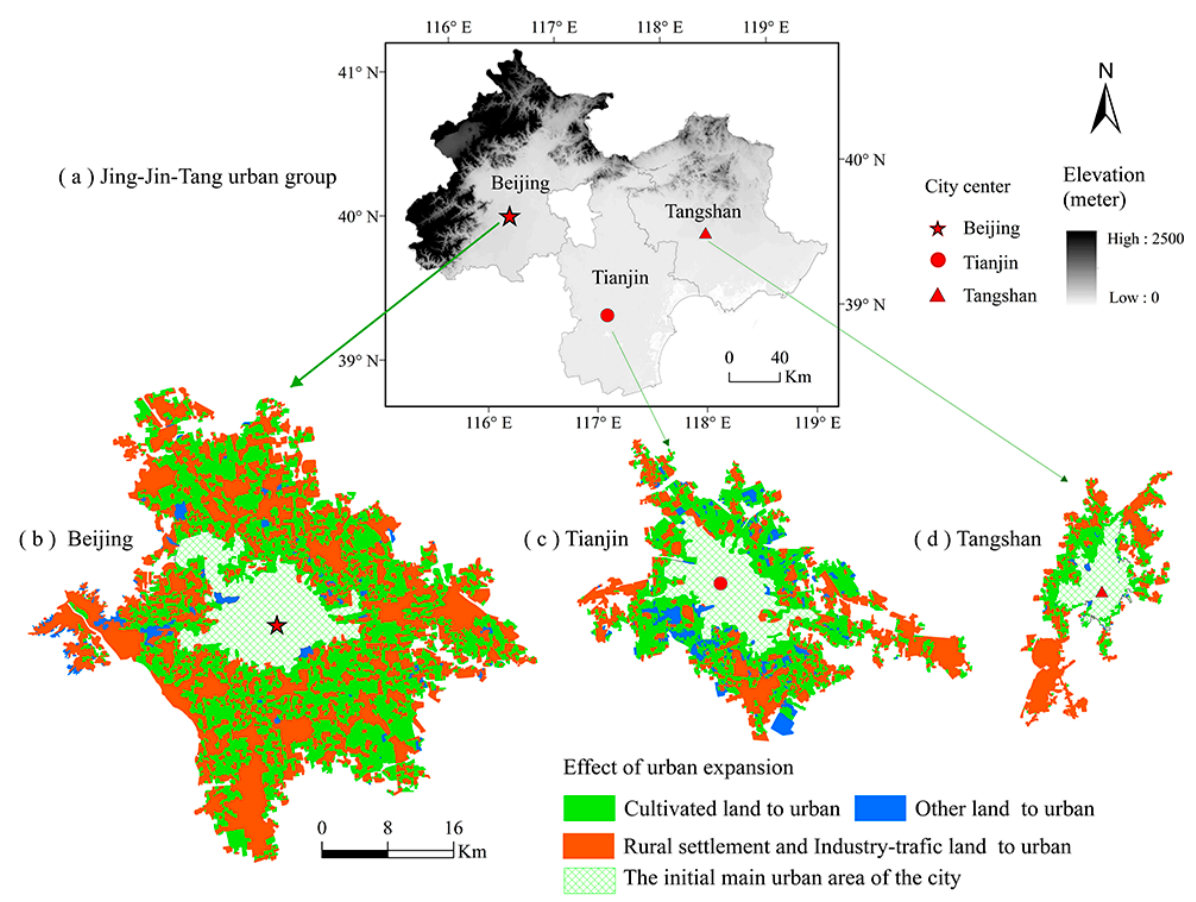

Figure 10. Transfer of land use types under the effect of urban expansion. (a) The study area of Beijing, Tianjin and Tangshan; (b) The effect of urban expansion on land use from 1973 to 2013 in Beijing; (c) The effect of urban expansion on land use from 1978 to 2013 in Tianjin; (d) The effect of urban expansion on land use from 1976 to 2013 in Tangshan.

For Beijing, the urban area mostly extended at the cost of cultivated land; since 1973, it has occupied $586.16 \mathrm{~km}^{2}$ of cultivated land, accounting for $50.84 \%$ of all newly built-up areas. This was followed by the conversion of rural residents' land to urban land, which was approximately $535.03 \mathrm{~km}^{2}$, accounting for $46.41 \%$ of the total expanding area. Cultivated land and rural settlement land converted at a rate of $14.65 \mathrm{~km}^{2}$ and $13.38 \mathrm{~km}^{2}$ per year, respectively. The hotpot expansion occurred during 2002-2003, and it was relatively less during 1973-1975 and 2006-2007. Before 2000, the rate of newly developed urban area from rural settlement land was slightly higher than that of cultivated land, but since 2000, cultivated land has become the main object of construction land expansion. 
In Tianjin city, the total expansion of the main urban district is $467.22 \mathrm{~km}^{2}$, which is also affecting the cultivated land and rural settlement land. Over the past 35 years, cultivated land and rural settlements are occupied by urbanization at an average rate of $6.83 \mathrm{~km}^{2}$ and $5.37 \mathrm{~km}^{2}$ each year. Since 1978 , it has occupied $239.18 \mathrm{~km}^{2}$ of cultivated land, accounting for $51.19 \%$ of all new expansion areas. The maximum expansion rate was during 2009-2011, whereas the minimum value was observed during 1998-2000, 1978-1979 and 1987-1993. Benefiting from the framework of "Regulations on the Protection of Basic Farmland" legal system in 1998, occupied rural settlements became the largest land source of expansion after 1998.

For Tangshan, the total expansion area was $98.71 \mathrm{~km}^{2}$, of this, the area from cultivated land was $50.91 \mathrm{~km}^{2}$, which was the largest component of the main expansion area, approximately $51.58 \%$, and the area from rural settlements was $45.64 \mathrm{~km}^{2}$, approximately $46.23 \%$. Moreover, the expansion area per year of cultivated land and rural residential area was $1.38 \mathrm{~km}^{2}$ and $1.23 \mathrm{~km}^{2}$, and the peak expansion area occurred in 2000; the rural settlement decreased more quickly than that of cultivated land before 2000, and cultivated land became the largest occupied object after 2000. The peak periods of expansion rate were 1976-1979, 1998-1999 and 2010-2011.

\subsection{The Interactions between Cities}

Because the interaction among cities is very complicated, it is difficult to find a quantitative way to depict the relationship among them. In this research, we introduce the modified Newton's gravity equation to describe the relative quantification relationship among the cities. Although this value is a relative parameter, it objectively reflects the interactions among cities. The descending order of interurban gravity (F) is Beijing and Tianjin (Jin-Jin), Beijing and Tangshan (Jing-Tang), Tianjin and Tangshan (Jin-Tang) (Figure 11). Beijing shows a greater impact on the other two cities. The interurban gravity showed various features in different periods. Before 2000, the interplay among the cities was micro. After 2000, it showed a greater increase in Jing-Jin and Jing-Tang. This may have resulted from Beijing's 2008 Olympic Games for which China submitted the bid in 2001. Meanwhile, the interurban gravity of Jin-Tang demonstrated macro change after 2009. An especially remarkable increase of gravity among the three cities is seen after 2009. The reason may be the 2008 Olympic Games in Beijing. With a series of development policies that have launched the better development of Jing-Jin-Ji metropolitan areas, the relationship among the cities will be highly strengthened.

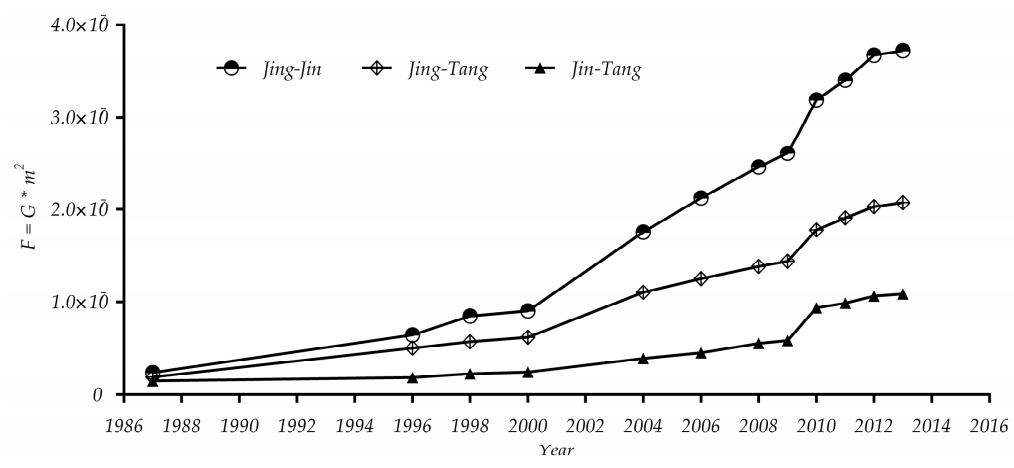

Figure 11. The interaction among cities in Beijing, Tianjin and Tangshan, by the modified law of gravitation.

\section{Discussion}

\subsection{Accuracy of Mapping Methods}

In this study, we used the method of visual interpretation by professionals, the classification accuracy depended on the professional background and interpretation ability of those researchers. Therefore, these aspects are particularly important for the quality control of the NLUD-C update [49]. 
Quality control is composed of two parts: repeated interpretation by different professionals and field verification. First, we randomly extracted $10 \%$ counties among all of the counties in China, and all dynamic polygons in the chosen counties were reinterpreted. Especially, repeated interpretation should follow these principle: accurate delineation of changes: thematic accuracy of cultivated and construction land should reach $90 \%$, and accuracy for other types should reach $80 \%$. The location accuracy of all types should be controlled within two pixels $(60 \mathrm{~m})$. Second, we took photos and recorded the situation of local land use/cover and its changes on tables, especially recording the impact of ecological and environmental engineering and urbanization process on land use. The field survey routes were not the same for different areas (Table 5). Based on the quality control, the position of objects located in remote sensing images was exactly, a consistent geometric image set was required. A TM image set geometrically rectified with 1:100,000 relief maps at 30m spatial resolution was built up for the NLUD-C updates. Geometric correction of the image set using ground control points was manually performed. The accuracy of geometric correction in terms of the relative position error for the same feature point does not exceed 2 pixels.

Table 5. Principles of the field survey routes.

\begin{tabular}{cc}
\hline Study Area $\left(\mathbf{k m}^{\mathbf{2}}\right)$ & Field Survey Routes $\mathbf{( k m )}$ \\
\hline$<100,000$ & $\geqslant 1000$ \\
$>100,000$ and $<250,000$ & $\geqslant 2000$ \\
$>250,000$ and $<500,000$ & $\geqslant 3000$ \\
$>500,000$ & $\geqslant 4000$ \\
\hline
\end{tabular}

\subsection{Topographical Features among Three Cities}

Over the past four decades, Beijing, Tianjin and Tangshan have all experienced dramatic urban expansion. Logically, this phenomenon might be related to the differences in topographical features in those cities, which mostly include river, coast, traffic development, and gentle terrain. Driven in such an environment, the city will give priority to expansion. First, Beijing, Tianjin and Tangshan are all located in the North China Plain; to the west of the cities are the Taihang Mountains, to the north are the Yanshan Mountains, further south of the cities are the Taishan Mountains, and to the east is Bohai Sea. Thus, the cities would expand toward the east or south at the regional level. Second, many topographic indicators could be also as the potential factors, such as the ruggedness of terrain, but many related studies have not yet clear, so we only discuss the impact of DEM on urban expansion here. At the city level, the average elevation of Beijing is $20-60 \mathrm{~m}$, and the southeast area is lower than the northwest area. In Tianjin, the mountainous area from northwest to southeast gradually declines, with a dustpan-shaped incline to Bohai. In Tangshan, the north is higher than the south, and from the west and northwest to east and southeast, the elevation becomes gentler towards the coast. Third, the powerful road transportation network accelerated the expansion in Beijing, and the coastal location created a good development opportunity for Tianjin and Tangshan. Moreover, all three cities could gain convenient marine transport and massive foreign directional investment from Binhai New Area.

\subsection{Planning and Policy among the Three Cities}

The detailed distinct characteristics in the directions and hot-zones of urban expansion in each city can be ascribed to the influence of urban planning and policy. The Urban Master Plan of Beijing (2004-2020) proposed the strategy of "Two axes, two belts, and multiple centers"; the "two axes" are the traditional Beijing axis and the Chang'an Street, and the "two belts" include the "Eastern development belt", which is north of Huairou district and Miyun district, along the Shunyi district and Tongzhou district in the southeast direction to Tianjin and Langfang City, and the "western ecological belt", which is Beijing's western mountainous area of the Yanqing, Changping line. The "multiple centers" are the urban construction areas within the scope of the different functional areas and in the 
new town in the "two belts". Beijing municipal government will be relocated to Tongzhou, which will have a great impact on the urban expansion of the future. As a consequence, the urban expansion in the southeast part of Tongzhou district and Shunyi district intensified during the period of 2004-2013. The Urban Master Plan of Tianjin (2005-2020) proposed the construction of a city spatial structure along "One axis, one belt, and three cities" in the Binhai New Area; the "one axis" is the axis along the Haihe River and the Beijing-Tianjin-Tanggu express highway; the "one belt" is the eastern coastal cities; and the "three cities" area is the core area of Binhai New Area, Hangu Metro and Dagang town. These have further driven the urbanization of Binhai New Area and even the inland areas, leading urban expansion in the southeast of Tianjin to a particular process along a corridor inland from coastal areas. The Urban Master Plan of Tangshan (2010-2020) proposed the development strategy of the "two belts", one of which is the development belt of the piedmont zone in the north of Tangshan, and the other is the coastal development belt in the south of Tangshan along with the Bohai areas. This is the consideration for strengthening cooperation with Chengde in the north and Beijing and Tianjin in the southeast, resulting in its shift in urban expansion direction after 2010.

Although the urban expansion area increased for all cities during the study period, it had different increasing magnitudes in different directions and different distances of hot-zones within each city, reflecting changes in the special regulations of urbanization with urban planning or policy in the specific periods. During the entire study period, the proportion of one of the urban expansion land types may have varied first and then decreased, or it may have remained stable or even increased for a certain part of each city; the periods of the most drastic land type change differed with direction and distance, demonstrating the relative dominance of urban development varying within cities over time, which may be adjusted according to urban planning, policy or other factors.

In summary, for Beijing, Tianjin, and Tangshan, the overall trend of urban expansion was restricted by topography conditions, whereas the characteristic of each urban expansion was driven by urban planning and policy.

\subsection{Recommendation on the Future Urban Expansion}

To prevent urban disorder sprawl, achieve land and energy conservation, and improve the running efficiency of city, we should construct a urban system which would be high density of living, less dependent on motor vehicles and mixed land-use. Based on the above analysis of the spatial and temporal distribution characteristics of Jing-Jin-Tang urban expansion, this study puts forward some proposals about the urban construction. In the past decades, Beijing has presented a relatively compact model of urban expansion, while Tianjin and Tangshan have shown a sharply sprawled expansion (Figure 8), and all the three cities have different levels of urban problems, such as the main urban area is crowding, the living distance is too long, the urban villages are still existing, and low efficiency of city informatization construction, so we advocate (1) speeding up the construction of new key towns to improve the compactness of the regional space; (2) insisting on it that the rail transit oriented land use model to improve regional traffic compactness; (3) strengthening the improvement of the urban village to improve the compactness of land use; and (4) accelerating the construction of information infrastructure to improve the efficiency of urban information.

\section{Conclusions}

This paper compared the spatial and temporal characteristics of the urbanization process in Beijing, Tianjin and Tangshan using the integration of urban growth, landscape metrics and the effect of main urban area expansion on other land use. The systematic study on the patterns of urban expansion in the Jing-Jin-Tang urban group can provide additional scientific resources to expound the characteristics of China's urbanization in this research field.

Quantified and compared spatiotemporal patterns of both the urbanized areas and the urban expansion of the main urban area from 1970 to 2013 in Beijing, Tianjin and Tangshan, which have experienced rapid urbanization with average annual urban growth rates of $7.28 \%, 3.9 \%$, and $0.97 \%$, 
respectively. Beijing presented a single choropleth map pattern, whereas Tianjin and Tangshan presented a double surface network pattern. Urban expansion in Beijing was mainly concentrated upon Ring 4 to Ring 6 in the northwest and southeast directions, and Tianjin's urban expansion was mainly fuelled by dramatic development of Binhai New Area in the southeast and Tianjin South Railway Station in the southwest. Naturally, the largest-scale southwestward expansion in Tangshan was influenced by the expansion of Beijing and Tianjin. The hot-zones of urbanization of the three cities were observed within the ranges of 7-25 km, 6-18 km, and 0-15 km, accounting for $93.49 \%$, $89.44 \%$ and $72.44 \%$ of the total expansion area, respectively. However, the forms were slightly different: for Beijing, the entire extended area showed an approximately normal distribution, whereas urban extension presented a skewed distribution in Tianjin and Tangshan. In Beijing, full urbanization was realized within the ring by 2013, which was approximately equivalent to the distance of Beijing Ring 5 .

Meanwhile, the expansion of the Beijing, Tianjin and Tangshan main urban districts directly impacts the regional land use, and the majority of newly developed urban land was converted from cultivated land and other built-up land in the past four decades. Beijing, Tianjin and Tangshan mostly extended along the cost of the cultivated land, occupying the $586.16 \mathrm{~km}^{2}, 239.18 \mathrm{~km}^{2}$, and $50.91 \mathrm{~km}^{2}$ of cultivated land, accounting for $50.84 \%, 51.19 \%$, and $51.58 \%$ of all newly built-up area, respectively. The conversion of cultivated land in the three cities mainly occurred in the southeast in Beijing and Tianjin, where Tangshan's was in the northeast, accounting for approximately $46.90 \%, 37.45 \%$, and $41.32 \%$ of the total, respectively. The differences in land use and economic, demographic and terrain factors led to the city centroid also showing great disparities. In Beijing, as the capital city of China, policy and terrain are the main factors influencing its spatial pattern. Because of the mountain area in the northwest, the city's expansion has moved southeast by approximately $2.57 \mathrm{~km}$. As a port city, the centroid of Tianjin's main urban area obviously moved towards the coastline, approximately $2.83 \mathrm{~km}$ to the southeast. Under the immense influences of Beijing and Tianjin, the centroid of the shift distance of Tangshan was $1.02 \mathrm{~km}$ to the southwest. Moreover, the starting time of urban growth in those cities was inconsistent; Beijing's was earlier than Tianjin and Tangshan.

Comprehensive the direction and distance analysis of urban development, it can be inferred that the direction weight of the Eastern Development Zone of Tongzhou, Shunyi and Yizhuang districts will be increased in the spider diagrams of the urban expansion of Beijing, and the scale of southeast (NE-E, E-SE, SE-S) will be continued to grow. The trend of Tianjin urban growth will also insist on Binhai New Area as the core development zone, while developing its northeastern Hangu Metro and its southwestern Dagang town, so the double surface network pattern of Tianjin will division from middle of Binhai New Area to northeastern and southwestern. Tangshan will continue to expand toward to the southwest near Beijing and Tianjin, meanwhile, it also will be close to Chengde in the north, and the spider diagrams of the urban expansion will be much sharper between northern and southern in Tangshan.

The annual urban expansion monitoring from 1970 to 2013 for the Jing-Jin-Tang urban group demonstrates that the time sequence of Landsat data can provide valuable urban development information for urban growth modeling and monitoring of urban planning effects. The spatiotemporal comparison methods of urban growth can be employed to study the spatial and temporal dynamic patterns of the other metropolitan areas in China. The landscape of urban expansion is influenced by temporal and spatial scales, so the general understanding on landscape metrics at regional or city level cannot reveal detailed within city landscape completely under the impacts of urban expansion. High-resolution urban landuse maps have important applications in urban planning and management [55]. Application of multiscale image data of urban expansion might have the potential to further improve our understanding.

Acknowledgments: The authors thank all the scientists who have participated in the establishment of the data of NLUD-C, who include all scientists and students in the Renewable Resources Division at the Institute of Remote Sensing and Digital Earth CAS. This paper was written under the auspices of the National Science and Technology Support Projects of China (No. 2014BAL01B01C). 
Author Contributions: Zengxiang Zhang and Na Li conceived and designed the experiments; Na Li and Linping Yang performed the experiments analyzed the data; Zengxiang Zhang, Xiao Wang, Fang Liu, Linping Yang contributed materials; $\mathrm{Na} \mathrm{Li}$ and Linping, Yang wrote the paper. All authors contributed extensively to the data collection and writing of this paper.

Conflicts of Interest: The authors declare no conflict of interest.

\section{References}

1. Foley, J.A.; DeFries, R.; Asner, G.P.; Barford, C.; Bonan, G.; Carpenter, S.R.; Chapin, F.S.; Coe, M.T.; Daily, G.C.; Gibbs, H.K.; et al. Global consequences of land use. Science 2005, 309, 570-574. [CrossRef] [PubMed]

2. Seto, K.C.; Fragkias, M.; Güneralp, B.; Reilly, M.K. A Meta-analysis of global urban land expansion. PLoS ONE 2011, 6. [CrossRef] [PubMed]

3. Wu, W.J.; Zhao, S.Q.; Zhu, C.J. A comparative study of urban expansion in Beijing, Tianjin and Shijiazhuang over the past three decades. Landsc. Urban Plan. 2014, 134, 93-106. [CrossRef]

4. Schneider, A.; Friedl, M.A.; Potere, D. Mapping global urban areas using MODIS 500-m data: New methods and datasets based on 'urban ecoregions'. Remote Sens. Environ. 2010, 114, 1733-1746. [CrossRef]

5. Solecki, W.; Seto, K.C.; Marcotullio, P.J. It's time for an urbanization science. Environment 2013, 55, $12-17$. [CrossRef]

6. Li, X.; Yeh, A.G.O. Modelling sustainable urban development by the integration of constrained cellular automata and GIS. Int. J. Geogr. Inf. Sci. 2000, 14, 131-152. [CrossRef]

7. $\quad \mathrm{Li}$, X.C.; Liu, X.P.; Gong, P. Integrating ensemble-urban cellular automata model with an uncertainty map to improve the performance of a single model. Int. J. Geogr. Inf. Sci. 2015, 29, 762-785. [CrossRef]

8. Turner, B.L., II; William, C.C.; Robert, W.K.; John, F.R.; Jessica, T.M.; William, B.M. The Earth as Transformed by Human Action: Global and Regional Changes in the Biosphere over the Past 300 Years; Cambridge University Press: Cambridge, UK, 1990.

9. Ji, W.; Ma, J.; Twibell, R.W.; Underhill, K. Characterizing urban sprawl using multi-stage remote sensing images and landscape metrics. Comput. Environ. Urban Syst. 2006, 30, 861-879. [CrossRef]

10. Yan, Y.; Zhang, C.; Hu, Y.F.; Kuang, W.H. Urban land-cover change and its impact on the ecosystem carbon storage in a Dryland city. Remote Sens. 2016, 8, 1-18. [CrossRef]

11. Johnson, M.P. Environmental impacts of urban sprawl: A survey of the literature and proposed research agenda. Environ. Plan. A 2001, 33, 717-735. [CrossRef]

12. Peiser, R. Decomposing urban sprawl. Town Plan. Rev. 2001, 72, 275-298.

13. Carlson, T.N.; Arthur, S.T. The impact of Land use/land cover changes due to urbanization on surface microclimate and hydrology: A satellite perspective. Glob. Planet. Chang. 2000, 25, 49-65. [CrossRef]

14. Xiao, J.Y.; Shen, Y.J.; Ge, J.F.; Tateishi, T.; Tang, C.Y.; Liang, Y.Q.; Huang, Z.Y. Evaluating urban expansion and land use change in Shijiazhuang, China, by using GIS and remote sensing. Landsc. Urban Plan. 2006, 75, 69-80. [CrossRef]

15. Grimm, N.B.; Faeth, S.H.; Golubiewski, N.E.; Redman, C.L.; Wu, J.; Bai, X.; Briggs, J. Global change and the ecology of cities. Science 2008, 319, 756-760. [CrossRef] [PubMed]

16. Grimm, N.B.; Grove, J.M.; Pickett, S.T.A.; Redman, C.L. Integrated approach to long-term studies of urban ecological systems. Biol. Sci. 2000, 50, 571-584. [CrossRef]

17. Wu, H.; Lu, P.; Ye, W.Z.; Keith, C.C. Assessing the effects of land use spatial structure on urban heat islands using HJ-1B remote sensing imagery in Wuhan, China. Int. J. Appl. Earth Obs. 2014, 32, 67-78. [CrossRef]

18. Kalnay, E.; Cai, M. Impact of urbanization and land-use change on climate. Nature 2003, 423, 528-531. [CrossRef] [PubMed]

19. Shao, Q.Q.; Sun, C.Y.; Liu, J.Y.; He, J.F.; Kuang, W.H.; Tao, S. Impact of urban expansion on meteorological observation data and overestimation to regional air temperature in China. J. Geogr. Sci. 2011, 21, 994-1006. [CrossRef]

20. Wang, J.; Huang, B.; Fu, D.J.; Peter, M.A. Spatiotemporal variation in surface urban heat island intensity and associated determinants across major Chinese cities. Remote Sens. 2015, 7, 3670-3689. [CrossRef]

21. Tan, M.H.; Li, X.B.; Xie, H.; Lu, C.H. Urban land expansion and arable land loss in China-A case study of Beijing-Tianjin-Hebei region. Land Use Policy 2005, 22, 187-196. [CrossRef] 
22. Bolca, M.; Turkyilmaz, B.; Kurucu, Y.; Altinbas, U.; Esetlili, M.T.; Gulgun, B. Determination of impact of urbanization on agricultural land and wetland land use in Balcovas Delta by remote sensing and GIS technique. Environ. Monit. Asses. 2007, 131, 409-419. [CrossRef] [PubMed]

23. Bai, J.H.; Huang, L.B.; Gao, Z.Q.; Lu, Q.Q.; Wang, J.J.; Zhao, Q.Q. Soil seed banks and their germination responses to cadmium and salinity stresses in coastal wetlands affected by reclamation and urbanization based on indoor and outdoor experiments. J. Hazard. Mater. 2014, 280, 295-303. [CrossRef] [PubMed]

24. Che, X.; Shang, J. Strategic environmental assessment for sustainable development in urbanization process in China. Chin. Geogr. Sci. 2004, 14, 148-152. [CrossRef]

25. Sarvestani, M.S.; Ibrahim, A.L.; Kanaroglou, P. Three decades of urban growth in the city of Shiraz, Iran: A remote sensing and geographic information systems application. Cities 2011, 28, 320-329. [CrossRef]

26. Du, P.J.; Li, X.L.; Cao, W.; Luo, Y.; Zhang, H.P. Monitoring urban land cover and vegetation change by multi-temporal remote sensing information. Min. Sci. Technol. 2010, 20, 922-932. [CrossRef]

27. Jat, M.K.; Garg, P.K.; Khare, D. Monitoring and modelling of urban sprawl using remote sensing and GIS techniques. Int. J. Appl. Earth Obs. 2008, 10, 26-43. [CrossRef]

28. Tian, G.J.; Liu, J.Y.; Xie, Y.C.; Yang, Z.F.; Zhuang, D.F.; Niu, Z. Analysis of spatio-temporal dynamic pattern and driving forces of urban land in China in 1990s using TM images and GIS. Cities 2005, 22, 400-410. [CrossRef]

29. Xu, X.L.; Min, X.B. Quantifying spatiotemporal patterns of urban expansion in China using remote sensing data. Cities 2013, 35, 104-113. [CrossRef]

30. Kang, W.H. Simulating dynamic urban expansion at regional scale in Beijing-Tianjin-Tangshan Metropolitan Area. J. Geogr. Sci. 2011, 21, 317-330. [CrossRef]

31. Lu, D.D. Function orientation and coordinating development of subregions with in the Jing-Jin-Ji Urban Agglomeration. Prog. Geogr. (China) 2015, 34, 265-270. [CrossRef]

32. Lu, D.D. Urbanization process and spatial sprawl in China. Urban Plan. Forum. 2007, 4, 47-52.

33. Yao, S.M.; Wang, C.; Zhang, L.C.; Roger, C.K.; Song, P. The influencing factors of resources and environments in the process of urbanization of China. Prog. Geogr. (China) 2008, 27, 94-100.

34. Jan, H.; Ban, Y.F. Urban growth and environmental impacts in Jing-Jin-Ji, the Yangtze, River Delta and the Pearl River Delta. Int. J. Appl. Earth Obs. 2014, 30, 42-55. [CrossRef]

35. Zhang, Y.; Zheng, H.M.; Yang, Z.F.; Li, Y.X.; Liu, G.Y.; Su, M.R.; Yin, X.N. Urban energy flow processes in the Beijing-Tianjin-Hebei (Jing-Jin-Ji) urban agglomeration: Combining multi-regional inpute output tables with ecological network analysis. J. Clean. Prod. 2016, 114, 243-256. [CrossRef]

36. Chen, J.; Gong, P.; He, C.Y.; Pu, R.L.; Shi, P.J. Land use/cover change detection using improved change vector analysis. Photogramm. Eng. Rem. Sens. 2003, 69, 369-379. [CrossRef]

37. Wu, Q.; Li, H.Q.; Wang, R.S.; Paulussen, J.; He, Y.; Wang, M.; Wang, B.H.; Wang, Z. Monitoring and predicting land use change in Beijing using remote sensing and GIS. Landsc. Urban Plan. 2006, 78, 322-333. [CrossRef]

38. He, C.Y.; Okada, N.; Zhang, Q.F.; Shi, P.J.; Li, J.G. Modelling dynamic urban expansion processes incorporating a potential model with cellular automata. Landsc. Urban Plan. 2008, 86, 79-91. [CrossRef]

39. He, C.Y.; Wei, A.N.; Shi, P.J.; Zhang, Q.F.; Zhao, Y.Y. Detecting land-use land-cover change in rural-urban fringe areas using extended change-vector analysis. Int. J. Appl. Earth Obs. 2011, 13, 572-585. [CrossRef]

40. Du, J.F.; Thill, J.C.; Peiser, R.B.; Feng, C.C. Urban land market and land-use changes in post-reform China-A case study of Beijing. Landsc. Urban Plan. 2014, 124, 118-128. [CrossRef]

41. Jia, K.; Liang, S.L.; Zhang, N.; Wei, X.Q.; Gu, X.F.; Zhao, X.; Yao, Y.J.; Xie, X.H. Land cover classification of finer resolution remote sensing data integrating temporal features from time series coarser resolution data. ISPRS J. Photogramm. 2014, 93, 49-55. [CrossRef]

42. Shen, Q.J.; Ma, J.W. Retrospect, analysis and thingking on post-earthquake reconstrucion planning of Tangshan City. Urban Plan. Forum 2008, 4, 17-28.

43. Shi, B.J.; Zhao, R.R.; Zhang, Y. Empirical analysis of tangshan economic growth and environmental pollution. Energ. Proced. 2011, 5, 2392-2396. [CrossRef]

44. Niu, J.R.; Oyediran, I.A.; Liu, D.; Huang, X.; Cui, Z.D.; Wang, H.J.; Shi, X.S. Quantitative foundation stability evaluation of urban karst area: Case study of Tangshan, China. Soils Found. 2015, 55, 493-503. [CrossRef]

45. Ministry of Construction of the People's Republic of China (GB/T50280-98). Standard for Basic Terminology of Urban Planning; China Architecture \& Building Press: Beijing, China, 1999.

46. Zhang, Z.X. Remote Sensing Monitoring of Urban Expansion in China; Star Map Press: Beijing, China, 2006. 
47. Zhang, Z.X.; Wang, X.; Zhao, X.L.; Liu, B.; Yi, L.; Zuo, L.J.; Wen, Q.K.; Liu, F.; Xu, J.Y.; Hu, S.G. A 2010 update of National Land Use/Cover Database of China at 1:100000 scale using medium spatial resolution satellite images. Remote Sens. Environ. 2014, 149, 142-154. [CrossRef]

48. Zeng, T.; Zhang, Z.X.; Zhao, X.L.; Wang, X.; Zuo, L.J. Evaluation of the 2010 MODIS Collection 5.1 land cover type product over China. Remote Sens. 2015, 7, 1981-2006. [CrossRef]

49. Liu, J.Y.; Zhan, J.Y.; Deng, X.Z. Spatio-temporal patterns and driving forces of urban land expansion in China during the economic reform era. Ambio 2005, 34, 450-455. [CrossRef] [PubMed]

50. Liu, J.Y.; Zhang, Q.; Hu, Y.F. Regional differences of China's urban expansion from late 20th to early 21st century based on remote sensing information. Chin. Geogr. Sci. 2012, 22, 1-14. [CrossRef]

51. Shi, L.F.; Liu, F.; Zhang, Z.X.; Zhao, X.L.; Liu, B.; Xu, J.Y.; Wen, Q.K.; Yi, L.; Hu, S.G. Spatial Differences of Coastal Urban Expansion in China from 1970s to 2013. Chin. Geogr. Sci. 2015, 25, 389-403. [CrossRef]

52. McGarigal, K.; Cushman, S.A.; Ene, E. FRAGSTATS v4: Spatial Pattern Analysis Program for Categorical and Continuous Maps. Computer Software Program Produced by the Authors at the University of Massachusetts, Amherst. Available online: http://www.umass.edu/landeco/research/fragstats/fragstats.html (accessed on 12 March 2016).

53. Wang, S.Y.; Liu, J.Y.; Zhang, Z.X.; Zhou, Q.B.; Wang, C.Y. Spatial pattern change of land use in China in recent 10 years. Acta Geogr. Sin. 2002, 57, 523-530.

54. Haynes, K.E.; Fotheringham, A.S. Gravity and Spatial Interaction Models; Sage-Publications: Beverly Hills, CA, USA, 1984; pp. 349-350.

55. Hu, T.Y.; Yang, J.; Li, X.C.; Gong, P. Mapping Urban Land Use by Using Landsat Images and Open Social Data. Remote Sens. 2016, 8, 1-18. [CrossRef]

(C) 2016 by the authors; licensee MDPI, Basel, Switzerland. This article is an open access article distributed under the terms and conditions of the Creative Commons Attribution (CC-BY) license (http://creativecommons.org/licenses/by/4.0/). 